\title{
Optimization design compressive strength of waste glass hybrid fiber
}

\section{ceramsite concrete}

\author{
Binghua Xia ${ }^{1, a}$, Yuancai Liu ${ }^{1, b}$ and Cheng Cheng ${ }^{2, c}$ \\ ${ }^{1}$ Experimentalist ,Experimental Teaching Center of Provinical Structural Engineering of Civil and \\ Engineering, Southwest forestry university, China \\ ${ }^{1}$ Professor ,Dept. of Civil and Engineering, Southwest forestry university, China \\ 2 Lecturer ,Dept. of Civil and Engineering, Southwest forestry university, China \\ amzatamd@126.com, b yuancailiu@126.com, c 527751552@qq.com
}

\begin{abstract}
Keywords: waste glass hybrid fiber ceramsite concrete, compressive strength, orthogonal experiment design, quadratic response surface design

Abstract: Experiment with intensity level for the LC30 ceramsite concrete as the research object, changing the content of cement, waste glass,HPP fiber, steel fiber by the orthogonal test to configure waste glass hybrid fiber ceramsite concrete samples, test them compressive strength in order to find the main factors which effect the compressive strength of waste glass hybrid fiber ceramsite concrete. Then use quadratic response surface design to optimal design aiming at the main factors. With the method of regression analysis according with the result of the experiment and the compressive strength prediction formula is established. The optimal mixture ratio of waste glass hybrid fiber ceramsite concrete is the volume of waste glass sand ratio is $15 \%$, water cement ratio is 0.5 , and HPP fiber content is $5.0 \mathrm{~kg} / \mathrm{m}^{3}$ and steel fiber volume content is $0.7 \% / \mathrm{m}^{3}$.
\end{abstract}

\section{Introduction}

Waste glass is common construction waste in the process of building demolition. Although some of them are recycled into new glass, add as fine aggregate in concrete, but the utilization rate of regeneration of waste glass is only $25 \%$ - 30\%, far lower than the European and American developed countries ${ }^{[1]}$. Europe and the United States developed countries on waste glass used in concrete has carried out extensive research, and achieved many practical researches ${ }^{[2-5]}$. Our country into a decade in the waste glass recycling research have also made many positive results ${ }^{[6-7]}$. Although waste glass as aggregate instead of normal concrete aggregate has a certain engineering practicability ${ }^{[8]}$, but with the increase of dosage, strength degradation of waste glass concrete will be fast, damage is also more brittle ${ }^{[9]}$. Therefore, in order to improve the waste glass the crack resistance of concrete, further reduce the weight of concrete, the experiments with the orthogonal design and the quadratic response surface method ${ }^{[10]}$ on the waste glass mixed fiber ceramsite concrete compressive strength tests. The purpose of the test is to get the waste glass fiber axis of ceramsite concrete compressive strength standard multivariate regression formula of compressive strength, and verify its availability, the waste glass cloth - layer type optimization of hybrid fiber reinforced lightweight aggregate concrete mixture ratio. 


\section{Test scheme design}

1 Tests of materials

(1) Cement

The experiment uses brand of "Red lion" Ordinary Portland cement( low alkali) which strength is P.O42.5, its physical and mechanical performance indicators is: the compressive strength of 3days and 28days are 21.4 MPa and 47.6 MPa; the flexural strength of 3days and 28days are 4.3 $\mathrm{MPa}$ and $8.2 \mathrm{MPa}$; the initial setting time is $152 \mathrm{~min}$ and the final setting time is $227 \mathrm{~min}$; the fineness of cement is $1.75 \%$; the density of cement is $3141 \mathrm{~kg} / \mathrm{m}^{3}$; volume stability test results qualified by the pat method; standard consistency water consumption is $26 \%$.

(2) Coarse aggregate

The Coarse aggregate is clay ceramsite which come from KeBao coal mine. The main parameters is shown in Table 1.

Table 1 Main parameters of haydite

\begin{tabular}{ccccccc}
\hline $\begin{array}{c}\text { Packing } \\
\text { density } \\
\left(\mathrm{kg} / \mathrm{m}^{3}\right)\end{array}$ & $\begin{array}{c}\text { Apparent } \\
\text { density } \\
\left(\mathrm{kg} / \mathrm{m}^{3}\right)\end{array}$ & $\begin{array}{c}\text { Cylindrical } \\
\text { compress } \\
\text { strength } \\
(\mathrm{MPa})\end{array}$ & $\begin{array}{c}\text { Porosity } \\
(\%)\end{array}$ & $\begin{array}{c}\text { Biggest } \\
\text { size } \\
(\mathrm{mm})\end{array}$ & $\begin{array}{c}\text { 1h Water } \\
\text { absorption } \\
(\%)\end{array}$ & Rating \\
\hline 778 & 1319 & 7.6 & $41 \%$ & 15.4 & $13.2 \%$ & 800 grades \\
\hline
\end{tabular}

(3) Fine aggregate

The fine aggregate is ordinary sand which come from Kunming. The biggest size is $5 \mathrm{~mm}$. The density of sand is $2647 \mathrm{~kg} / \mathrm{m}^{3}$. The packing density is $1480 \mathrm{~kg} / \mathrm{m}^{3}$. The fineness modulus is 2.56 .

(4) Waste glass

The experiment uses waste glass as another fine aggregate which come from ordinary glass by grinding processing. The biggest size is $5 \mathrm{~mm}$. The density of waste glass is $2522 \mathrm{~kg} / \mathrm{m}^{3}$. The packing density is $1486 \mathrm{~kg} / \mathrm{m}^{3}$. The fineness modulus is 2.83 .

(5) Fiber

The experiment using two kinds of fibers. The HPP fiber is type toughening polypropylene synthetic crude fibre. The steel fiber is flat steel fiber. The main parameters is shown in Table 2.

Tab. 2 Fiber main performance index

\begin{tabular}{cccccccc}
\hline Material category & Shape & $\begin{array}{c}\text { Equivalent } \\
\text { diameter } \\
(\mathrm{mm})\end{array}$ & $\begin{array}{c}\text { Specifications } \\
(\mathrm{mm})\end{array}$ & $\begin{array}{c}\text { Elongation } \\
\text { at break } \\
(\%)\end{array}$ & $\begin{array}{c}\text { Density } \\
\left(\mathrm{g} / \mathrm{cm}^{3}\right)\end{array}$ & $\begin{array}{c}\text { Tensile } \\
\text { strength } \\
(\mathrm{MPa})\end{array}$ & $\begin{array}{c}\text { Modulus of } \\
\text { elasticity } \\
\left(\mathrm{N} / \mathrm{mm}^{2}\right)\end{array}$ \\
\hline steel & flat & 0.30 & 25 & - & 7.8 & $300-500$ & $206 \times 10^{3}$ \\
polypropylene & crawler & 0.35 & 25 & $15 \% \pm 5 \%$ & 0.91 & $>450$ & $>4000$ \\
\hline
\end{tabular}

2 The design idea of the test program

Test using absolute volume method ${ }^{[11]}$ try to match and adjust the benchmark set of light aggregate concrete mixture ratio, then using orthogonal experiment method for concrete mix proportion design of modified benchmark group. By test data analysis we can find the significant factors and level range of which affect the compressive strength of waste glass hybrid fiber ceramsite concrete. Then using quadric surface response method to optimize design. Eventually we can get significant factors and the compressive strength of the regression equation and optimal mixture ratio. The type of electro-hydraulic servo universal testing machine is CSS-WAW600 
which come from southwest forestry university instrument sharing platform .Benchmark set of ceramsite concrete mixture ratio is shown in Table 3. Test arrangement is shown in Table 4. The lay-out drawing of fiber is shown in figue 1.

Tab.3 Ceramsite concrete mixture ratio of baseline group

\begin{tabular}{cccc}
\hline Cement $\left(\mathrm{kg} / \mathrm{m}^{3}\right)$ & Water $\left(\mathrm{kg} / \mathrm{m}^{3}\right)$ & $\begin{array}{c}\text { Coarse aggregate } \\
\left(\mathrm{kg} / \mathrm{m}^{3}\right)\end{array}$ & Sand $\left(\mathrm{kg} / \mathrm{m}^{3}\right)$ \\
\hline 430 & 248 & 602 & 641 \\
\hline
\end{tabular}

Tab.4 Project schedule of the test

\begin{tabular}{|c|c|c|c|c|c|}
\hline \multirow[b]{2}{*}{ Test categories } & \multicolumn{2}{|c|}{ Number of specimens (/group) } & \multirow[b]{2}{*}{$\begin{array}{l}\text { Curing } \\
\text { time } \\
\text { (d) }\end{array}$} & \multirow[b]{2}{*}{$\begin{array}{l}\text { Curing } \\
\text { conditions }\end{array}$} & \multirow[b]{2}{*}{$\begin{array}{l}\text { Specimen size } \\
(\mathrm{mm})\end{array}$} \\
\hline & $\begin{array}{c}\text { Standard } \\
\text { compression test }\end{array}$ & $\begin{array}{c}\text { Axial } \\
\text { compression } \\
\text { test }\end{array}$ & & & \\
\hline The benchmark set of test & 3 & 3 & $7 \mathrm{~d} 、 28 \mathrm{~d}$ & Standard & $\begin{array}{l}150 \times 150 \times 150 \\
150 \times 150 \times 300\end{array}$ \\
\hline Orthogonal test & 3 & 3 & $7 \mathrm{~d}, 28 \mathrm{~d}$ & Standard & $\begin{array}{l}150 \times 150 \times 150 \\
150 \times 150 \times 300\end{array}$ \\
\hline $\begin{array}{c}\text { Quadratic response surface } \\
\text { test }\end{array}$ & 3 & 3 & $7 \mathrm{~d}, 28 \mathrm{~d}$ & Standard & $\begin{array}{l}150 \times 150 \times 150 \\
150 \times 150 \times 300\end{array}$ \\
\hline
\end{tabular}

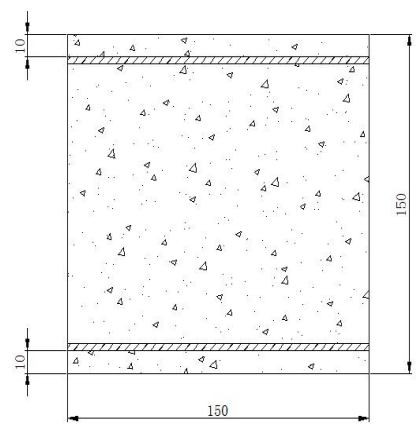

Figure.1 The arrangement plan of fiber

\section{The orthogonal experiment design and data analysis}

1 Orthogonal test design

Test using $\mathrm{L}_{9}\left(3^{4}\right)$ as orthogonal test table , The volume of waste glass sand ratio, water cement ratio , HPP fiber content $\left(\mathrm{kg} / \mathrm{m}^{3}\right)$ and steel fiber volume content $\left(\% / \mathrm{m}^{3}\right)$ as variable factors. Each variable factors consider three levels get orthogonal test table is shown in Table 5. The orthogonal experiment and test results is shown in Table 6.

2 The orthogonal experiment data analysis

(1)Intuitive analysis

By calculating the mean of assessment index $\mathrm{K}_{\mathrm{i}}$ and extremum $\mathrm{R}_{\mathrm{i}}$ of factors, we can get the best combination test and the analysis of the influence of factors on the evaluation index of primary and secondary order. The $\mathrm{K}_{\mathrm{i}}$ and $\mathrm{R}_{\mathrm{i}}$ are shown in Table 7and Table 8 . 
Tab.5 Orthogonal test design table

\begin{tabular}{ccccc} 
Lactors & $\begin{array}{c}\text { The volume of } \\
\text { waste glass } \\
\text { sand ratio } \\
\mathrm{A}(\%)\end{array}$ & $\begin{array}{c}\text { Water cement } \\
\text { ratio } \\
\mathrm{B}\end{array}$ & $\begin{array}{c}\text { HPP fiber } \\
\text { content } \\
\mathrm{C}\left(\mathrm{kg} / \mathrm{m}^{3}\right)\end{array}$ & $\begin{array}{c}\text { Steel fiber } \\
\text { volume content } \\
\mathrm{D}\left(\% / \mathrm{m}^{3}\right)\end{array}$ \\
\hline 1 & 11 & 0.63 & 4.4 & 0.33 \\
2 & 22 & 0.59 & 4.95 & 0.44 \\
3 & 33 & 0.56 & 5.5 & 0.55 \\
\hline
\end{tabular}

Tab.6 Mix ratio and test results of orthogonal test

\begin{tabular}{|c|c|c|c|c|c|c|c|c|}
\hline Factors & \multirow[t]{2}{*}{ A } & \multirow[t]{2}{*}{ B } & \multirow[t]{2}{*}{ C } & \multirow[t]{2}{*}{ D } & \multicolumn{2}{|c|}{$\begin{array}{c}\text { Standard compressive } \\
\text { strength } \\
(\mathrm{MPa}) \\
\end{array}$} & \multicolumn{2}{|c|}{$\begin{array}{c}\text { Axial compres sive } \\
\text { strength } \\
(\mathrm{MPa})\end{array}$} \\
\hline Test no. & & & & & $7 d$ & $28 \mathrm{~d}$ & $7 \mathrm{~d}$ & $28 d$ \\
\hline 1 & 11 & 0.63 & 4.4 & 0.33 & 22.66 & 25.56 & 16.42 & 17.81 \\
\hline 2 & 11 & 0.59 & 4.95 & 0.44 & 17.86 & 26.51 & 14.55 & 16.24 \\
\hline 3 & 11 & 0.56 & 5.5 & 0.55 & 21.36 & 29.09 & 18.95 & 21.96 \\
\hline 4 & 22 & 0.63 & 4.95 & 0.55 & 18.30 & 22.68 & 16.80 & 19.59 \\
\hline 5 & 22 & 0.59 & 5.5 & 0.33 & 23.66 & 26.22 & 16.82 & 19.51 \\
\hline 6 & 22 & 0.56 & 4.4 & 0.44 & 24.15 & 31.31 & 19.96 & 24.74 \\
\hline 7 & 33 & 0.63 & 5.5 & 0.44 & 19.53 & 26.44 & 16.45 & 22.32 \\
\hline 8 & 33 & 0.59 & 4.4 & 0.55 & 16.64 & 21.05 & 15.67 & 18.28 \\
\hline 9 & 33 & 0.56 & 4.95 & 0.33 & 23.25 & 27.34 & 16.84 & 21.43 \\
\hline
\end{tabular}

Tab.7 The calculation table of mean value $\mathrm{K}_{\mathrm{i}}$

\begin{tabular}{|c|c|c|c|c|c|c|c|c|c|c|c|c|c|}
\hline \multirow{2}{*}{$\begin{array}{l}\text { Factors } \\
\text { Assesshrent } \\
\text { indicators }\end{array}$} & \multicolumn{3}{|c|}{$\mathrm{A}$} & \multicolumn{3}{|c|}{ B } & \multicolumn{3}{|c|}{$\mathrm{C}$} & \multicolumn{3}{|c|}{$\mathrm{D}$} & \multirow{2}{*}{ best of breed } \\
\hline & $\mathrm{K}_{\mathrm{l}}$ & $\mathrm{K}_{2}$ & $\mathrm{~K}_{3}$ & $\mathrm{~K}_{\mathrm{l}}$ & $\mathrm{K}_{2}$ & $\mathrm{~K}_{3}$ & $\mathrm{~K}_{1}$ & $\mathrm{~K}_{2}$ & $\mathrm{~K}_{3}$ & $\mathrm{~K}_{\mathrm{l}}$ & $\mathrm{K}_{2}$ & $\mathrm{~K}_{3}$ & \\
\hline $\begin{array}{c}\text { Standard } \\
\text { compressive } \\
\text { strength(7d) }\end{array}$ & 20.63 & 22.04 & 19.81 & 20.16 & 19.39 & 22.92 & 21.15 & 19.80 & 21.52 & 23.19 & 20.51 & 18.77 & $\mathrm{~A}_{2} \mathrm{~B}_{3} \mathrm{C}_{3} \mathrm{D}_{1}$ \\
\hline $\begin{array}{c}\text { Standard } \\
\text { compressive } \\
\text { strength(28d) }\end{array}$ & 27.05 & 26.74 & 24.94 & 24.89 & 24.59 & 29.25 & 25.97 & 25.51 & 27.25 & 26.37 & 28.08 & 24.27 & $A_{1} B_{3} C_{3} D_{2}$ \\
\hline $\begin{array}{l}\text { Axial } \\
\text { compressive } \\
\text { strength(7d) }\end{array}$ & 16.64 & 17.86 & 16.32 & 16.55 & 15.68 & 18.58 & 17.35 & 16.06 & 17.40 & 16.69 & 16.98 & 17.14 & $\mathrm{~A}_{2} \mathrm{~B}_{3} \mathrm{C}_{3} \mathrm{D}_{3}$ \\
\hline $\begin{array}{c}\text { Axial } \\
\text { compressive } \\
\text { strength(28d) }\end{array}$ & 18.67 & 21.28 & 20.67 & 19.90 & 18.01 & 22.71 & 20.27 & 19.08 & 21.26 & 19.58 & 21.10 & 19.94 & $\mathrm{~A}_{2} \mathrm{~B}_{3} \mathrm{C}_{3} \mathrm{D}_{2}$ \\
\hline
\end{tabular}


Tab.8 The calculation table of extreme value $\mathrm{R}_{\mathrm{i}}$

\begin{tabular}{|c|c|c|c|c|c|c|}
\hline Factors & $\mathrm{A}$ & B & $\mathrm{C}$ & $\mathrm{D}$ & \multirow{2}{*}{$\begin{array}{l}\text { Main } \\
\text { factors }\end{array}$} & \multirow{2}{*}{$\begin{array}{l}\text { Secondary } \\
\text { factors }\end{array}$} \\
\hline $\begin{array}{l}\text { Assessment } \\
\text { indicators }\end{array}$ & $\mathrm{R}$ & $\mathrm{R}$ & $\mathrm{R}$ & $\mathrm{R}$ & & \\
\hline $\begin{array}{c}\text { Standard } \\
\text { compressive } \\
\text { strength }(7 d)\end{array}$ & 2.23 & 3.53 & 1.71 & 4.42 & B、D & $A 、 C$ \\
\hline $\begin{array}{c}\text { Standard } \\
\text { compressive } \\
\text { strength }(28 d)\end{array}$ & 2.11 & 4.65 & 1.74 & 3.81 & B、D & $A 、 C$ \\
\hline $\begin{array}{l}\text { Axial compressive } \\
\text { strength }(7 \mathrm{~d})\end{array}$ & 1.54 & 2.90 & 1.34 & 0.45 & B & $A 、 C 、 D$ \\
\hline $\begin{array}{l}\text { Axial compressive } \\
\text { strength }(28 \mathrm{~d})\end{array}$ & 2.61 & 4.70 & 2.18 & 1.52 & $A 、 B$ & C、D \\
\hline
\end{tabular}

(2)Analysis of variance

Based on experiment data of variance analysis can determine the influence of various factors on the test results, thus a reliable basis for the next test. Variance analysis of orthogonal experiment is shown in Table 9.

Tab.9 The variance analysis table of orthogonal test

\begin{tabular}{|c|c|c|c|c|c|}
\hline \multirow{2}{*}{ Test item } & \multicolumn{4}{|c|}{ F value } & \multirow{2}{*}{ Critical value } \\
\hline & A & $\mathrm{B}$ & $\mathrm{C}$ & $\mathrm{D}$ & \\
\hline $\begin{array}{c}\text { Standard } \\
\text { compressive } \\
\text { strength }(7 d)\end{array}$ & 1.56 & $4.24 * *$ & 1.00 & $6.10 * *$ & $F_{0.1}(2,6)=3.463$ \\
\hline $\begin{array}{c}\text { Standard } \\
\text { compressive } \\
\text { strength }(28 \mathrm{~d})\end{array}$ & 1.59 & $8.35^{* *}$ & 1.00 & $4.49 * *$ & $\mathrm{~F}_{0.05}(2,6)=5.143$ \\
\hline $\begin{array}{l}\text { Axial compressive } \\
\text { strength }(7 \mathrm{~d})\end{array}$ & $20.37 * *$ & $43.06^{* *}$ & $11.21 *$ & 1.00 & $\mathrm{~F}_{0.05}(2,2)=19$ \\
\hline $\begin{array}{c}\text { Axial compressive } \\
\text { strength }(28 \mathrm{~d})\end{array}$ & 2.97 & $8.90 * *$ & 1.89 & 1.00 & $\mathrm{~F}_{0.05}(2,4)=6.944$ \\
\hline
\end{tabular}

Through the orthogonal experiment of comprehensive analysis of intuitive analysis and variance analysis, we found that the size of the order each factors influence on compressive strength of waste glass hybrid fiber ceramsite concrete is water cement ratio $>$ steel fiber volume content $>$ the volume of waste glass sand ratio $>$ HPP fiber content. Water cement ratio is a very significant influence factor of 7 d's and 28 d's compressive strength of waste glass cloth layer type hybrid fiber ceramsite concrete. Steel fiber volume content is a very significant influence factor of $7 \mathrm{~d}$ 's and 28 d's standard compressive strength of waste glass cloth layer type hybrid fiber ceramsite concrete. The volume of waste glass sand ratio is a very significant influence factor of $7 \mathrm{~d}$ 's and $28 \mathrm{~d}$ 's axial compressive strength of waste glass cloth layer type hybrid fiber ceramsite concrete. Model steel fiber content for the $7 \mathrm{~d}$ 's axial compressive strength of waste glass cloth layer type hybrid fiber ceramsite concrete effect is obvious. So overall consideration, we can get the Optimum combination 
is $A_{2} B_{3} C_{3} D_{2}$ 。

\section{Quadratic response surface design of experiment and data analysis}

1 Quadratic response surface experiment design

Response surface design method is a kind of optimization design method has been developing rapidly in recent years. For the influence of multivariate problems it can be obtained by mathematical modeling analysis. We can get the optimum combination and the main factors by using orthogonal test design. But the optimum combination is not the discrete points's. However, the response surface design rules can be continuous function equation. So, the experiment uses the quadratic response surface design method as further optimization design. From the orthogonal experiment analysis, choose water cement ratio, the volume of waste glass sand ratio and steel fiber volume content as main factors of quadratic response surface experiment design. Standard compressive strength $(7 \mathrm{~d}, 28 \mathrm{~d})$ and axial compressive strength $(7 \mathrm{~d}, 28 \mathrm{~d})$ as the objective function use central composite design to optimize experiment design. Finally, using regression analysis and variance analysis to the test results. Three factors response surface design table is shown in Table 10 .

Tab.10 The design table of three factor response surface

\begin{tabular}{lccc}
\hline Factors & $\begin{array}{c}\text { The volume of } \\
\text { waste glass sand } \\
\text { ratio (\%) }\end{array}$ & Water cement ratio & $\begin{array}{c}\text { Steel fiber volume } \\
\text { content }\left(\% / \mathrm{m}^{3}\right)\end{array}$ \\
\cline { 2 - 4 } Code value & $\mathrm{A}$ & $\mathrm{B}$ & $\mathrm{D}$ \\
\hline Upper level $(+1)$ & 25 & 0.60 & 0.7 \\
Lower level $(-1)$ & 15 & 0.50 & 0.3 \\
Zero level $(0)$ & 20 & 0.55 & 0.5 \\
Change range $\left(\triangle_{\mathrm{i}}\right)$ & 5 & 0.05 & 0.2 \\
\hline
\end{tabular}

2 Quadratic response surface experiment data analysis

The Design - Expert software is used for experimental Design arrangement and data processing. Mix proportion design of test and test results is show $\mathrm{n}$ in Table 11. According to the volume of waste glass sand ratio,water cement ratio and Steel fiber volume content 3 factors to the correlation of compressive strength, we can establish a formula of them. The regression equations as Eq. 1 to Eq. 4. Analysis of variance of regression equations is shown in Table 12.

According to Table 12 and each regression equations's $\mathrm{R}^{2}$ show that the regression equations are very significant, them have good applicability. Using the Design Expert software for three factors quadratic response surface experiment to optimization analysis, the optimal combination of the compressive strength test were introduced, compare to the test results, we get the Table 13.

$$
\begin{aligned}
& Y_{1}=64.26-570.07 x_{1}+29.5 x_{3}+797.14 x_{1}^{2}-92.19 x_{2}^{2}-13.20 x_{3}^{2}+559.88 x_{1} x_{2}-94.75 x_{1} x_{3} \quad\left(\quad \mathrm{R}^{2}=0.828\right) \\
& \text { ( Eq 1) } \\
& Y_{2}=72.55 x_{1}+30.55 x_{3}+830.83 x_{1}^{2}-92.42 x_{2}^{2}-13.85 x_{3}^{2}+560.45 x_{1} x_{2}-96.5 x_{1} x_{3} \quad\left(\mathrm{R}^{2}=0.84\right) \quad(\text { Eq 2) } \\
& Y_{3}=-40.16-372.33 x_{1}+293.26 x_{2}+36.65 x_{3}+932.90 x_{1}^{2}-247.56 x_{2}^{2}-27.27 x_{3}^{2}-20.12 x_{2} x_{3} \quad\left(\quad \mathrm{R}^{2}=0.86\right) \\
& Y_{4}=-28.83-374.97 x_{1}+279.82 x_{2}+24.71 x_{3}+939.27 x_{1}^{2}-244.31 x_{2}^{2}-26.53 x_{3}^{2} \quad\left(\mathrm{R}^{2}=0.87\right)
\end{aligned}
$$


$Y_{1}$ - standard compressive strength(7d), $\mathrm{MPa}$;

$Y_{2}$ - standard compressive strength(28d), $\mathrm{MPa}$;

$Y_{3}$ - axial compressive strength(7d), MPa;

$Y_{4}$ - axial compressive strength(28d), $\mathrm{MPa}$;

$x_{1}$ - the volume of waste glass sand ratio, $\%$;

$x_{2}$ - water cement ratio;

$x_{3}$ - steel fiber volume content, $\% / \mathrm{m}^{3}$.

The Eq. 1 to Eq. 4's application conditions are $x_{1} \in[10 \%, 30 \%], x_{2} \in[0.5,0.6], x_{3} \in[0.5,0.7]$ and HPP fiber content is $5 \mathrm{~kg} / \mathrm{m}^{3}$.

Tab.11 Mix ratio and test results of three factor response surface test

\begin{tabular}{|c|c|c|c|c|c|c|c|}
\hline \multirow[t]{2}{*}{ Groups } & \multicolumn{3}{|c|}{ Factors } & \multicolumn{2}{|c|}{$\begin{array}{c}\text { Standard } \\
\text { compressive } \\
\text { strength }(\mathrm{MPa})\end{array}$} & \multicolumn{2}{|c|}{$\begin{array}{l}\text { Axial compressive } \\
\text { strength }(\mathrm{MPa})\end{array}$} \\
\hline & A & B & $\mathrm{D}$ & $7 d$ & $28 \mathrm{~d}$ & $7 d$ & $28 \mathrm{~d}$ \\
\hline 1 & 0.25 & 0.60 & 0.30 & 24.19 & 31.72 & 17.80 & 22.32 \\
\hline 2 & 0.12 & 0.55 & 0.50 & 24.18 & 31.71 & 21.63 & 26.15 \\
\hline 3 & 0.25 & 0.60 & 0.70 & 19.30 & 26.82 & 14.88 & 19.41 \\
\hline 4 & 0.25 & 0.50 & 0.30 & 17.88 & 25.41 & 15.16 & 19.69 \\
\hline 5 & 0.15 & 0.50 & 0.30 & 17.94 & 25.46 & 15.57 & 20.05 \\
\hline 6 & 0.20 & 0.55 & 0.50 & 17.94 & 25.20 & 16.65 & 21.12 \\
\hline 7 & 0.20 & 0.55 & 0.84 & 16.72 & 23.98 & 12.02 & 16.50 \\
\hline 8 & 0.15 & 0.60 & 0.30 & 16.73 & 23.99 & 16.12 & 20.60 \\
\hline 9 & 0.20 & 0.55 & 0.16 & 17.49 & 24.75 & 12.07 & 16.55 \\
\hline 10 & 0.20 & 0.55 & 0.50 & 16.83 & 24.09 & 14.29 & 18.76 \\
\hline 11 & 0.20 & 0.55 & 0.50 & 18.54 & 25.78 & 17.00 & 21.34 \\
\hline 12 & 0.15 & 0.60 & 0.70 & 17.69 & 25.24 & 15.96 & 20.31 \\
\hline 13 & 0.28 & 0.55 & 0.50 & 23.50 & 31.06 & 20.74 & 25.09 \\
\hline 14 & 0.20 & 0.55 & 0.50 & 17.91 & 25.46 & 12.37 & 16.73 \\
\hline 15 & 0.25 & 0.50 & 0.70 & 15.98 & 23.52 & 15.52 & 19.87 \\
\hline 16 & 0.20 & 0.55 & 0.50 & 17.01 & 24.56 & 14.40 & 18.75 \\
\hline 17 & 0.20 & 0.55 & 0.50 & 18.56 & 25.94 & 15.59 & 20.00 \\
\hline 18 & 0.15 & 0.50 & 0.70 & 17.77 & 25.14 & 13.74 & 18.15 \\
\hline 19 & 0.20 & 0.47 & 0.50 & 18.27 & 25.65 & 12.89 & 17.30 \\
\hline 20 & 0.20 & 0.63 & 0.50 & 17.43 & 24.81 & 14.37 & 18.79 \\
\hline
\end{tabular}


Tab.12 The variance analysis table of regression equations

\begin{tabular}{cccccc}
\hline Equations & $\begin{array}{c}\text { Degrees } \\
\text { of } \\
\text { freedom }\end{array}$ & $\begin{array}{c}\text { Mean } \\
\text { square } \\
\text { error }\end{array}$ & F value & P value & $\begin{array}{c}\text { significan } \\
\mathrm{t}\end{array}$ \\
\hline Eq.1 & 9 & 2.43 & 6.69 & 0.0019 & $* *$ \\
Eq.2 & 9 & 2.48 & 7.50 & 0.0013 & $* *$ \\
Eq.3 & 9 & 2.54 & 8.70 & 0.0007 & $* *$ \\
Eq.4 & 9 & 2.54 & 10.68 & 0.0002 & $* *$ \\
\hline * - very significant & & & &
\end{tabular}

Tab.13 The test results of Optimal mix ratio

\begin{tabular}{|c|c|c|c|c|c|c|c|c|}
\hline \multirow[t]{2}{*}{ Test groups } & \multirow[t]{2}{*}{ A } & \multirow[t]{2}{*}{ B } & \multirow[t]{2}{*}{$\mathrm{C}$} & \multirow[t]{2}{*}{$\mathrm{D}$} & \multicolumn{2}{|c|}{$\begin{array}{c}\text { The test standard } \\
\text { compressive strength } \\
(\mathrm{MPa})\end{array}$} & \multicolumn{2}{|c|}{$\begin{array}{l}\text { The test axial } \\
\text { compressive } \\
\text { strength }(\mathrm{MPa})\end{array}$} \\
\hline & & & & & $7 d$ & $28 \mathrm{~d}$ & $7 d$ & $28 \mathrm{~d}$ \\
\hline 1 & 20 & 0.55 & 5.0 & 0.5 & 18.06 & 26.07 & 15.40 & 20.12 \\
\hline 2 & 20 & 0.55 & 5.0 & 0.5 & 16.85 & 27.36 & 15.63 & 19.89 \\
\hline 3 & 15 & 0.60 & 5.0 & 0.7 & 17.70 & 26.48 & 15.34 & 21.13 \\
\hline 4 & 15 & 0.50 & 5.0 & 0.7 & 16.06 & 28.58 & 13.66 & 26.12 \\
\hline
\end{tabular}

\section{Conclusions}

1. By the orthogonal experiment intuitive analysis and variance analysis show that the main factors which influence on standard compressive strength of waste glass hybrid fiber ceramsite concrete are water cement ratio and steel fiber volume content. However, the main factor which influence on $7 \mathrm{~d}$ axial compressive strength of waste glass hybrid fiber ceramsite concrete is water cement ratio. The main factor which influence on $28 \mathrm{~d}$ axial compressive strength of waste glass hybrid fiber ceramsite concrete are the volume of waste glass sand ratio and water cement ratio. Get the optimized combination is $\mathrm{A}_{2} \mathrm{~B}_{3} \mathrm{C}_{3} \mathrm{D}_{2}$, namely the volume of waste glass sand ratio is $22 \%$, water cement ratio is 0.56 ,HPP fiber content is $4.95 \mathrm{~kg} / \mathrm{m}^{3}$ and steel fiber volume content is $0.55 \% / \mathrm{m}^{3}$.

2. Using the quadratic response surface design method to test again optimization design was carried out, make HPP fiber content is $5.0 \mathrm{~kg} / \mathrm{m}^{3}$, consider the volume of waste glass sand ratio, water cement ratio and steel fiber volume content as main factors. Using the Design - Expert software Design to three factors quadratic response surface test, regression analysis and variance analysis. The results of the experiments show that the volume of waste glass sand ratio, water cement ratio and steel fiber volume content have significant correlation, each regression equation's $\mathrm{R}^{2}>0.8$ shoe that these equations are available.

3. Using the orthogonal experiment design and quadratic response surface design can optimize the test design. After verification, show that the optimum mixture ratio is the volume of waste glass sand ratio is $15 \%$, water cement ratio is 0.5 , and HPP fiber content is $5.0 \mathrm{~kg} / \mathrm{m}^{3}$ and steel fiber volume content is $0.7 \% / \mathrm{m}^{3}$. Experimental measurements that the $28 \mathrm{~d}$ 's standard compressive strength and axial compressive strength of waste glass hybrid fiber ceramsite concrete respectively 
are $28.58 \mathrm{MPa}$ and $26.12 \mathrm{MPa}$.

\section{Acknowledgements}

This work was financially supported by Scientific research fund project in yunnan province department of education "Tension and compression of the opposite sex concrete flexural stress strain characteristic test research"(project number: 2015Y297),the Provincial Special Major Project of Forest Engineering (project number: 501035), the Experimental Teaching Center of Provincial Structural Engineering (project number: 501042), and the key Discipline Project of Forest Engineering in SWFU (project number: 47002801)

\section{References}

[1] KE Guo-jun, BAI Ji-ping,TAN Da-wei. A Review on the Reuse of Waste Glasses in the Cement Concrete [J]. Journal of University of South China (Science and Technology), 2010 , 24(3) : $96-102$.

[2]LAMCS , POONCS , CHAN D. Enhancing the performance of pre-cast concrete blocks by incorporating waste glass-ASR consideration [J]. Cement \& Concrete Composites, 2007(29) : saturation and Building Materials, 2008(22):713-720.

[3]JLEE G,LING T C,W0NG Y Let al. Effects of crushed glass cullet sizes, casting methods and pozzolanic materials on ASR of concrete blocks[J].Construction and Building Material,2011(25) : 2611-2618.

[4]SACCANI N,BIGNOZZ M C.ASR expansion behavior of recycled glass fine aggregates in concrete[J].Cement and Concrete Research, 2010(40): 531-536.

[5]WANG H Y,HUANG W L. Durability of self-consolidating concrete using waste LCD glass[J].2010,24(6) : 1008-1013.

[6] LIU Guang-yan,QIN Rong,WANG Xiao-feng. Experimental investigation on the strength and construction property of the waste glasses coarse aggregate concrete [J]. Concrete, 2011 (3): 121-124.

[7] YANG Feng-ling,JI Yin-hang,LI Yu-shou,XUNYong. Experimental study on waste glass fine aggregate concrete[J]. Concrete, 2011(9): 81-86.

[8] Gan Yuanchu,Zeng Chao,Ke Guojun,Li Song. Experimental study on the flexural behaviour of waste-glass-powder reinforced concrete beams [J]. Building Structure, 2014(11): 78-81.

[9] XIA Binghua,LIU Yuancai,XU Guolin. Experimental research on compressive strength of waste glass concrete $[\mathrm{J}]$. Concrete, 2013 (70):26-29.

[10] He Wei,Xue Wei-dong, Tang Bin. Optimization design of experiment method and data analysis [M]. Beijing: Chemical industry press,2012.

[11] Zhang Yingli. Modern concrete mixture ratio design handbook (second edition) [M]. Beijing: people's traffic press, 2013. 